\title{
Application and performance evaluation of desulfurization wastewater spray drying technology
}

\author{
Zhang Shanshan ${ }^{1, *}$, Wang Renlei ${ }^{1}$, Tang Guorui ${ }^{1}$, Dai YU ${ }^{1}$ \\ ${ }^{1}$ Huadian electric power research institute Co., LTD. , Hangzhou, 310030
}

\begin{abstract}
In order to realize zero discharge of desulfurization wastewater, spray drying technology of desulfurization wastewater was used in $2 \times 330 \mathrm{MW}$ unit of a power plant. Its principle was to use a rotary atomizer for atomization, and a part of hot flue gas was drawn from the SCR denitrification reactor and air preheater into the drying tower, the heat was used to evaporate the desulfurization wastewater in a spray drying tower. The salt in the waste water was mixed with the dust, which was collected and removed by the electric dust remover. Then the water vapor was mixed with the flue gas and finally enters the desulfurization tower.The field test was carried out under the condition that the unit load was $100 \%$ and the amount of desulfurization wastewater treated was $5.1 \mathrm{~m}^{3} / \mathrm{h}$. The results showed that the hot smoke gas volume of drying tower was about $64896 \mathrm{~m}^{3} / \mathrm{h}$, The smoke temperature at the inlet and outlet of the drying tower were $335^{\circ} \mathrm{C}$ and $205^{\circ} \mathrm{C}$ respectively, the moisture content of drying products was only $0.05 \%$. The content of $\mathrm{HCl}$ in the flue gas at the inlet and outlet of the drying tower were $55 \mathrm{mg} / \mathrm{L}$ and $195 \mathrm{mg} / \mathrm{L}$ respectively, the mass fractions of $\mathrm{Cl}$ removal and $\mathrm{Cl}$ volatilization in desulfurization wastewater were $87.7 \%$ and $12.3 \%$ respectively. The increase of $\mathrm{Cl}$ content in the dried products had little effect on the utilization of fly ash.
\end{abstract}

\section{The introduction}

Limestone-gypsum wet desulfurization process was the most widely used $\mathrm{SO}_{2}$ removal technology in thermal power industry, it account for about $90 \%$ of the capacity of the units that have adopted desulfurization process. Its advantages were mature and reliable technology, high desulfurization efficiency, wide application range and low process $\operatorname{cost}^{[1]}$. The desulfurization wastewater from wet desulfurization is one of the most difficult wastewater to be treated in thermal power plant because of its characteristics of high salt, heavy metal, complex composition, corrosiveness and scaling.

At present, the research and application of zeroemission desulphurization wastewater technology was in its infancy. The zero-emission desulphurization wastewater had been realized in baotou power plant, jurong power plant, yangcheng power plant, etc. The mainstream technology route of these zero-emission desulphurization wastewater projects was "pretreatment + concentration reduction + terminal solidification" ${ }^{[2-5]}$. If the amount of desulfurization wastewater was small, it could be pretreated and solidified directly. If the amount of desulfurization wastewater was large, pretreatment +concentration reduction could be carried out before solidification treatment. At present, chemical softening + filtration was generally adopted in pretreatment technology, among which chemical softening mainly includes lime-sodium carbonate softening, lime-flue gas softening, naoh-sodium carbonate softening, etc.
Filtration includes tube microfiltration, ultrafiltration, nanofiltration, etc ${ }^{[5-7]}$.Concentration reduction technologies mainly included membrane concentration and thermal concentration, among which membrane concentration technologies mainly include nanofiltration membrane, positive osmosis membrane, reverse osmosis membrane and electrodialysis membrane ${ }^{[8-10]}$, while thermal concentration technologies mainly include multi-effect evaporation, steam recompression evaporation and low-temperature flue gas waste heat evaporation ${ }^{[11-12]}$. At the end of solidification technology mainly include evaporation pond, evaporation crystallization technology and flue gas evaporation drying technology ${ }^{[13-18]}$, which was divided into multiple effect evaporation and crystallization technology evaporation crystallization process (MED) and steam compression (MVR/TVR) evaporation crystallization process, dry flue gas evaporation technology was the main flue gas evaporation drying technology and the bypass flue gas evaporation drying technology, which was divided into two-fluid atomization technology, mechanical rotary atomizing technology, fluidized bed drying technology and so on.

\section{Application of zero emission tech- nology of desulfurization wastewater spray drying}

\footnotetext{
* Corresponding author: zssncepu@163.com
} 


\subsection{The technology principle}

Zero discharge spray drying technology of desulfurization wastewater was one of by-pass flue gas evaporation drying technology.Its principle was to use a rotary atomizer for atomization, and a part of hot flue gas was drawn from the SCR denitrification reactor and air preheater into the drying tower, the heat was used to evaporate the desulfurization wastewater in a spray drying tower. The salt in the waste water was mixed with the dust, which was collected and removed by the electric dust remover. Then the water vapor was mixed with the flue gas and finally enters the desulfurization tower. Thus the zero discharge treatment of desulfurization wastewater was completed.

\subsection{Overview of engineering applications}

The 330MW coal-fired power unit of a power plant adopts the limestone-gypsum wet desulfurization technology. In the actual operation process, a certain amount of desulfurization wastewater was generated. The power plant chooses the desulfurization wastewater spray drying technology for zero-emission treatment. According to the transformation technical agreement and related requirements, under the condition of designed coal, when the boiler was $100 \%$ loaded, the designed treatment capacity of the drying tower was $5 \mathrm{~m}^{3} / \mathrm{h}$, and the dry slag moisture content at the bottom of the drying tower was less than $0.2 \%$. The relevant performance guarantee values were shown in table 1 .

Table 1. Performance guarantee value.

\begin{tabular}{|c|c|}
\hline Item & Guarantee value \\
\hline $\begin{array}{c}\text { Design wastewater treatment } \\
\text { volume }\end{array}$ & $5 \mathrm{~m}^{3} / \mathrm{h}$ \\
\hline $\begin{array}{c}\text { Moisture content of drying } \\
\text { products }\end{array}$ & $\leq 0.2 \%$ \\
\hline Boiler efficiency influence value & $\leq 0.5 \%$ \\
\hline $\begin{array}{c}\text { Drying tower outlet smoke } \\
\text { temperature }\end{array}$ & $\leq 180^{\circ} \mathrm{C}$ \\
\hline
\end{tabular}

\section{Evaluation of zero emission techn- ology of desulfurization wastewater spray drying}

During the test, the unit run stably, the load rate fluctuation of the unit was not more than $5 \%$, and the average load rate was about $99.0 \%$. The inlet and outlet baffle doors of the drying tower were open to a certain degree, so as to ensure that the hot smoke volume introduced into the drying tower was stable. The desulphurization waste spray drying device and the main instruments operate normally, and the amount of waste water treated by the desulphurization waste water spray drying device was stable at about $5.1 \mathrm{~m}^{3} / \mathrm{h}$. The test results were as follows.

\subsection{Water quality and quantity of desulfurization wastewater}

During the test, several parallel samples of desulfurization wastewater were taken from the waste water tank every day, and the water quality of the sampled wastewater was tested. The amount of desulfurization wastewater at the entrance of drying tower was measured by fortaflow-s10c1-00c ultrasonic flowmeter in Japan. The test results of water quality and water volume of desulfurization wastewater were shown in table 2.

Table 2. Test results of desulfurization wastewater quality and quantity.

\begin{tabular}{|c|c|c|}
\hline Water quality of the project & Unit & Data \\
\hline Soluble solid & $\mathrm{mg} / \mathrm{L}$ & 41400 \\
\hline Suspended solids & $\mathrm{mg} / \mathrm{L}$ & 7850 \\
\hline $\mathrm{Cl}^{-}$ & $\mathrm{mg} / \mathrm{L}$ & 14500 \\
\hline $\mathrm{pH}$ & $/$ & 7.97 \\
\hline $\begin{array}{c}\text { On-site test of } \\
\text { desulfurization wastewater }\end{array}$ & $\mathrm{m}^{3} / \mathrm{h}$ & 5.1 \\
\hline $\begin{array}{c}\text { Online desulfurization } \\
\text { wastewater volume }\end{array}$ & $\mathrm{m}^{3} / \mathrm{h}$ & 5.0 \\
\hline
\end{tabular}

It could be seen from table 2,the dissolved solid content of desulfurization wastewater was $41400 \mathrm{mg} / \mathrm{L}$, the $\mathrm{Cl}$ content was $14500 \mathrm{mg} / \mathrm{L}$, the on-site test of desulfurization wastewater was $5.1 \mathrm{~m}^{3} / \mathrm{h}$, and the flow error with the online instrument was $2 \%$, indicating that the electromagnetic flowmeter of desulfurization wastewater at the entrance of the drying tower was accurate, and the amount of desulfurization wastewater injected into the drying tower was $5.1 \mathrm{~m}^{3} / \mathrm{h}$, which meet the test requirements.

\subsection{Moisture content of drying products}

During the test, ash samples were collected at the bottom of the dry tower twice a day, about $100 \mathrm{~g}$ each time. The collected slag samples were weighed in the beaker respectively, and then put into the oven to dry together until constant weight, and then put into the dryer to cool to room temperature and weigh. According to the weight change of slag samples before and after drying, the moisture content of the dry products at the bottom of the drying tower was calculated to be about $0.05 \%$, which met the requirements of the technical agreement $(\leq 0.2 \%)$.

\subsection{The temperature change of drying tower}

During the test, the flue gas temperature at the inlet and outlet of the drying tower was tested respectively. The temperature curves of the inlet and outlet of the drying tower were shown in figure 1. 


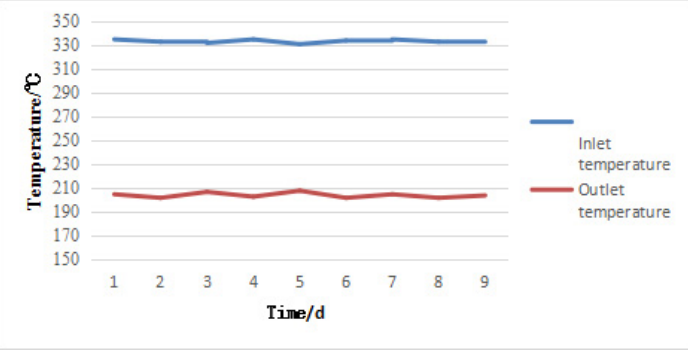

Fig. 1. Temperature curve of flue gas at inlet and outlet of drying tower.

It could be seen from figure 1,drying tower entrance smoke temperature maintained at about $335^{\circ} \mathrm{C}$, the high temperature flue gas in the tower of dry desulfurization wastewater for atomization evaporation, drying tower outlet smoke temperature down to about $205{ }^{\circ} \mathrm{C}$, drying tower inlet and outlet flue gas temperature was $130{ }^{\circ} \mathrm{C}$, drying tower outlet smoke temperature significantly higher than the technical agreement requirements (outlet flue gas temperature $\leqslant 180{ }^{\circ} \mathrm{C}$ ), description of drying tower was introduced into hot smoke volume may be larger.

\subsection{Influence on boiler efficiency}

The desulfurization wastewater spray drying technology USES the newly built drying tower in the bypass to conduct atomization and evaporation of desulfurization wastewater in the drying tower after extracting the hightemperature flue gas from the denitrification unit and in front of the air preheater. After extracting a certain amount of high-temperature flue gas, the amount of high-temperature flue gas entering the air preheater was reduced to some extent. On the premise that the heat exchange efficiency of the air preheater remains unchanged, the amount of heat obtained by the primary air and the secondary air through the air preheater was reduced, which had a certain impact on the efficiency of the boiler. During the test, parameters such as hot exhaust gas volume, total exhaust gas volume of the boiler, inlet and outlet smoke temperature of the air preheater were tested. Table 3 was the influence table of desulfurization wastewater atomization drying technology on the air preheater during the test.

Table 3. Effect of spray drying technology on air preheater for desulfurization wastewater

\begin{tabular}{|c|c|c|}
\hline Item & Unit & Data \\
\hline Desulfurization wastewater & $\mathrm{m}^{3} / \mathrm{h}$ & 5 \\
\hline Draw hot smoke volume & $\mathrm{m}^{3} / \mathrm{h}$ & 64896 \\
\hline Total smoke gas & $\mathrm{m}^{3} / \mathrm{h}$ & 998760 \\
\hline $\begin{array}{c}\text { The percentage of the total amount of } \\
\text { smoke }\end{array}$ & $\%$ & 6.5 \\
\hline $\begin{array}{c}\text { Dry tower entrance smoke temperature } \\
\text { Drying tower outlet smoke temperature }\end{array}$ & ${ }^{\circ} \mathrm{C}$ & 335 \\
\hline Air preheater inlet smoke temperature & ${ }^{\circ} \mathrm{C}$ & 205 \\
\hline
\end{tabular}

\begin{tabular}{|c|c|c|}
\hline Air preheater outlet smoke temperature & ${ }^{\circ} \mathrm{C}$ & 140 \\
\hline
\end{tabular}

It could be seen from table 3, the average amount of hot smoke gas extracted from the drying tower was about $64896 \mathrm{~m}^{3} / \mathrm{h}$, accounting for $6.5 \%$ of the total flue gas of the boiler. According to the calculation, the overall efficiency of the boiler decreased by $5.5 \%$, slightly exceeding the design value (5\%). Combined with figure 2, it could be judged that the amount of hot smoke was relatively large, resulting in higher smoke temperature at the outlet of the drying tower, which had a certain impact on the boiler efficiency.

\subsection{Chlorine balance of drying tower}

The chlorine balance in the drying tower was shown in figure2. The content of chlorine in the drying tower was calculated in 1 hour, as shown in table 4 .

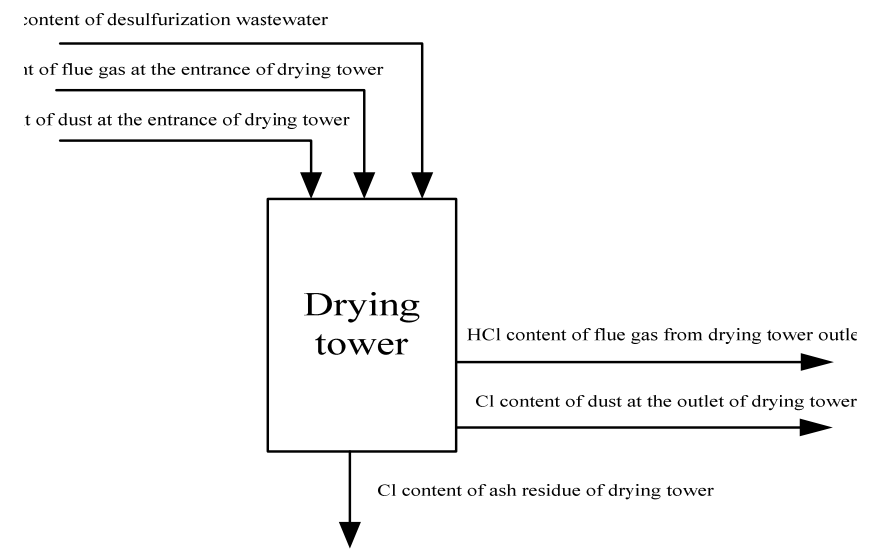

Fig. 2. Chlorine equilibrium diagram of drying tower.

Table 4. The content of chlorine in drying tower.

\begin{tabular}{|c|c|c|c|}
\hline Item & $\begin{array}{c}\text { Flow } \\
\text { rate/concentration }\end{array}$ & Cl content & The total Cl \\
\hline $\begin{array}{c}\text { The desulfurization } \\
\text { wastewater }\end{array}$ & $5.1 \mathrm{~m}^{3} / \mathrm{h}$ & $14500 \mathrm{mg} / \mathrm{L}$ & $74.0 \mathrm{~kg} / \mathrm{h}$ \\
\hline $\begin{array}{c}\text { Smoke from the } \\
\text { entrance of the } \\
\text { drying tower }\end{array}$ & $64896 \mathrm{~m}^{3} / \mathrm{h}$ & $55 \mathrm{mg} / \mathrm{m}^{3}$ & $3.6 \mathrm{~kg} / \mathrm{h}$ \\
\hline $\begin{array}{c}\text { Dust at the entrance } \\
\text { of the drying tower }\end{array}$ & $24 \mathrm{~g} / \mathrm{m}^{3}$ & $0.12 \%$ & $1.9 \mathrm{~kg} / \mathrm{h}$ \\
\hline $\begin{array}{c}\text { Flue gas from } \\
\text { drying tower outlet }\end{array}$ & $64975 \mathrm{~m}^{3} / \mathrm{h}$ & $195 \mathrm{mg} / \mathrm{m}^{3}$ & $12.7 \mathrm{~kg} / \mathrm{h}$ \\
\hline $\begin{array}{c}\text { Dust at the outlet of } \\
\text { the drying tower }\end{array}$ & $30 \mathrm{~g} / \mathrm{m}^{3}$ & $3.23 \%$ & $63.0 \mathrm{~kg} / \mathrm{h}$ \\
\hline $\begin{array}{c}\text { Dry ash at lower } \\
\text { end of tower }\end{array}$ & $1.7 \mathrm{~g} / \mathrm{m}^{3}$ & $3.22 \%$ & $3.6 \mathrm{~kg} / \mathrm{h}$ \\
\hline
\end{tabular}

It could be seen from figure 2 and table 4 , the main sources of chlorine in the drying tower include chlorine in the desulfurization wastewater, $\mathrm{HCl}$ in the flue gas at the inlet of the drying tower and chlorine in the dust at the inlet of the drying tower, among which the chlorine content in the desulfurization wastewater was the main one. The effluent of chlorine from the drying tower mainly includes $\mathrm{HCl}$ in the flue gas at the outlet of the drying tower, chlorine in the dust at the outlet of the 
drying tower and chlorine in the low slag of the drying tower. The total chlorine content at the inlet and outlet of the drying tower were $79.5 \mathrm{~kg} / \mathrm{h}$ and $79.3 \mathrm{~kg} / \mathrm{h}$ respectively, and the chlorine content in the drying tower was basically balanced.

\subsection{Chlorine removal and volatilization of desulfurization wastewater}

After the desulfurization wastewater was atomized and dried by the drying tower, most of $\mathrm{Cl}$ was collected and removed by the electric dust remover, and a small part of $\mathrm{Cl}$ volatilization return to the absorption tower with the flue gas. As can be seen from table 4, the content of gaseous $\mathrm{Cl}$ in the flue gas at the inlet of the drying tower was $55 \mathrm{mg} / \mathrm{m}^{3}$, and the content of gaseous $\mathrm{Cl}$ in the outlet flue gas was $195 \mathrm{mg} / \mathrm{m}^{3}$, an increase of $140 \mathrm{mg} / \mathrm{m}^{3}$, mainly due to the increase of $\mathrm{HCl}$ content in the outlet flue gas caused by chlorine volatilization of desulfurization wastewater. According to the calculation, the mass fraction of chlorine removal from desulfurization wastewater was $87.7 \%$, and the mass fraction of $\mathrm{Cl}$ volatilization was about $12.3 \%$, indicating that $12.3 \% \mathrm{Cl}$ in desulfurization wastewater returns to the desulfurization tower. When the amount of desulfurization wastewater remains unchanged, the concentration of chlorine ions in the desulfurization tower would increase. In the actual operation process, the desulfurization wastewater was discharged continuously and the volume flow of the desulfurization wastewater increases, which would maintain the $\mathrm{Cl}$ concentration in the desulfurization tower within a certain reasonable range.

\subsection{Effect on fly ash}

After atomization and evaporation of desulfurization wastewater through drying tower, most $\mathrm{Cl}$ was removed by mixing with dust. According to the one-hour plan, $\mathrm{Cl}$ in desulfurization wastewater mixed with dust was $64.9 \mathrm{~kg} / \mathrm{h}$, and the total content of $\mathrm{Cl}$ in fly ash was $66.6 \mathrm{~kg} / \mathrm{h}$, while the amount of fly ash produced by one boiler was $24.0 \mathrm{t} / \mathrm{h}$, and the proportion of $\mathrm{Cl}$ in fly ash was $0.28 \%$. According to the mixing ratio design principle of fly ash concrete, if fly ash was incorporated into cement at $20 \%$, the content of $\mathrm{Cl}$ in cement was $0.056 \%$, which meet the requirements of gb175-2007 "general Portland cement" of $0.06 \%^{[19]}$. Therefore, bypass flue evaporation had little effect on the recycling utilization of fly ash.

\section{Conclusion}

Experimental results showed that:

(1) The smoke temperature at the inlet and outlet of the drying tower were $335^{\circ} \mathrm{C}$ and $205^{\circ} \mathrm{C}$, the outlet smoke temperature of drying tower were obviously higher than the requirements of technical agreement (outlet smoke temperature $\leqslant 180{ }^{\circ} \mathrm{C}$ ). The overall efficiency of the boiler decreased by $5.5 \%$, which exceeded the design value $(5 \%)$. It could be judged that the amount of hot smoke was too large, resulting in a higher smoke temperature at the outlet of the drying tower, which had a certain impact on the boiler efficiency. The moisture content of drying products at the bottom of drying tower was about $0.05 \%$.

(2) The content of chlorine in drying tower was basically balanced, the total chlorine content at the inlet and outlet of the drying tower were $79.5 \mathrm{~kg} / \mathrm{h}$ and $79.3 \mathrm{~kg} / \mathrm{h}$, the main sources of chlorine were chlorine in desulfurization wastewater, $\mathrm{HCl}$ in flue gas and chlorine in dust at the inlet of the drying tower. The main effluents of chlorine were $\mathrm{HCl}$ in flue gas, chlorine in dust and chlorine in low slag. The increase of $\mathrm{Cl}$ element in fly ash was $64.9 \mathrm{~kg} / \mathrm{h}$, which had little impact on the resource utilization of fly ash.

(3) The removal mass fraction of $\mathrm{Cl}$ in desulfurization wastewater was about $87.7 \%$,the mass fraction of $\mathrm{Cl}$ volatilization was $12.3 \%$.Chlorine volatilization of desulfurization wastewater results in the increase of $\mathrm{HCl}$ content in export flue gas, which would increase the amount of desulfurization wastewater and the amount of added water in the process..

(4) After the desulfurization waste water was atomized and evaporated by the by-pass drying tower, the salt in the waste water was collected and removed along with the dust, and the evaporated water vapor entered the desulfurization tower along with the flue gas. After the desulfurization tower condenses, the desulfurization process water was indirectly supplemented, so as to realize zero discharge of desulfurization wastewater.

\section{References}

1. MA Shuangchen,YU Weijing,JIA Shaguang,etal. Research and application progresses of flue gas desulfurization(FGD)wastewater treatment technologies in coal-fired plants [J].Chemical Industry and Engineering Progress,2016,35 (2) :255-262.

2. WU Yiwei. Study on the wastewater treatment in limestone-gypsum wet FGD process[J].Electric Power,2006,39(4):75-78.

3. ZHANG Guang-wen,SUN Mo-jie,ZHANG Puxuan,LIU Xiao-meng. The Study of the Feasibility of Zero Discharge of Desulfurization Wastewater in Coal-fired Power Plant[J].Journal of Northeast Dianli University,2014,34(5):87-91.

4. ZHANG Jingrui,LIU Qinbin,LI Fei,etal. Design and application of flue gas duct waste heat evaporation based zero discharge technology for treatment of desulfurization wastewater from thermal power plants[J].Electric Power Technology and Environmental Protection,32(3):16- 20.

5. MO Hua,WU Lai-gui,ZHOU Jia-gui.Development and application of zero wastewater discharge system for coal-fired power plant[J]. Journal of Hefei University of Technology(Natural Science),2013,36(11):1368-1372.

6. LIU Yapeng,WANG Jinlei,CHEN Jingshuo,etal.Optimization of FGD Wastewater Pretreat- 
ment Technique for Thermal Power Plant and Test Studies on Tubular Crossflow Microfiltration Process[J]. Electric Power,2016,49(2) : 153- 158.

7. Shao Guohua,Fang Dai.Application of MBC zero liquid discharge technology to desulfurization wastewater treatment in a power plant[J].Industrial Water Treatment,2016,36( 8) : 109-112.

8. YI Xue-nong,WANG Yu-lin,YAN Zhi-hua,DONG Yan-ling.Pilot Study on Reverse Osmosis Membrane for Treatment of Wet Desulfurization Wastewater[J].China Water $\&$ Wastewater, ,20162016,32(1):67-70.

9. LIAN Kunzhou,CHEN Jingshuo,LIU Zhaoxia, etal.Experimental Study on the Reduction Treatment of Desulfurization Wastewater in Power Plants by Membrane[J]. Electric Power ,2016,49 ( 2) : 148152 .

10. LAURA Chekli, SHERUB Phuntsho, JUNG Eun Kim. A comprehensive review of hybrid forward osmosis systems Performance, applications and future prospects [J].Journal of Membrane Science, 2016,497:430-449.

11. Wang Kehui,Xu Zhiqing,Jiang Fen,etal.Zeroemission Pilot Study on Industrial Desulfurized Wastewater Evaporation Using Waste Heat from Thermal Power Plant[J].Environmental Science and Management,2015,40(11):105-108.

12. WANG Ke-hui,JIANG Fen,XU Zhi-qing,etal. Industrial Zero Discharge by Evaporating and Concentrating Desulfurized Wastewater with Waste Heat in Coal-Fired Power Plant [J]. Power \& Energy,2015,36(6):854-857.

13. WU Shuaishuai,LI Hongzhi,CHEN Hongwei,etal. Numerical study on spray evaporation process of desulfurization wastewater in flue duct[J].Thermal Power Generation,2015,44(12):31-36.

14. Kang Meiqiang,Deng Jiajia,Chen Deqi,etal.Analysis on the Feasibility of Dseulfurization Wastewater Evaporation Treatment in Flue Gas Duct Without Pollution Discharge[J].Journal of Civil,Architectural \& Environmental Engineering,2013,35(S):238-240.

15. MA Shuangchen,YU Weijing,JIA Shaoguang,etal. Properties of flue duct evaporation products by desulfurization waste water in coal-fired power plants[J].Journal of Chinese Society of Power Engineering,2016,36(11):894-900.

16. ZHANG Jing-rui,LIANG Hai-shan,ZHENG Yuming,etal.Application of zero liquid discharge system of the desulfurization wastewater based on bypass flue evaporation system in thermal power plants[J].Environmental Engineering,2017,35(10):59.

17. Wang Kehui,Jiang Fen,Xu Zhiqing,etal. Experimental research on high temperature atomizing evaporation for desulfurization wastewater treatment in theramal power plant[J].Environmental Engineering,2015,33(S):6063.
18. MA Shuangchen,WU Kai,WAN Zhongcheng, etal.Effect of evaporation bypass on water and chlorine balance in desulfurization system of a coalfired power plant[J].Journal of Chinese Society of Power Engineering,,2018,38(4):298-307.

19. GB 175-2007, Common Portlan Cement[S].Beijing: Standards Press of China, 2007(in Chinese). 